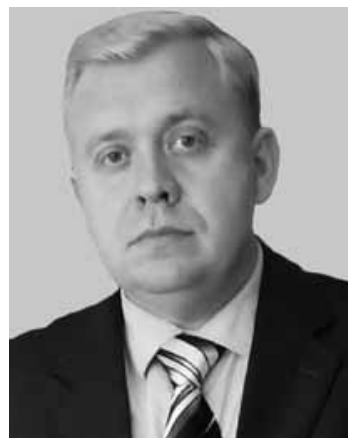

\author{
Prof. O.A. Oparin, O.M. Maliar, \\ PHD Yu.G. Fedchenko
}

Kharkiv Medical Academy of Postgraduate Education

\title{
Features of the clinical course and motor- secretory disorders in gastroesophageal reflux disease in overweight patients
}

Topicality. Today, GERD is relevant and one of the most controversial issues in gastroenterology. This is a chronic recurrent disease caused by spontaneous, regularly recurrent injection of gastric and / or duodenal contents into the esophagus, which leads to damage to the lower esophagus [1]. The leading factors in the development of GERD are violations of the motor-secretory function of the stomach and esophagus. Despite numerous scientific studies, the mechanisms of motor secretion have not been fully studied, in particular in GERD with concomitant obesity $[2,3,5]$. Obesity contributes to the development of GERD, leads to an increase in intragastric pressure and an increase in the pressure gradient between the stomach and esophagus, slowing down the evacuation and motor function of the upper gastrointestinal tract. It has been suggested that the chronic inflammatory process that accompanies obesity is associated with increased excretion of proinflammatory cytokines of adipocyte origin (leptin - LEP) and decreased synthesis of antiinflammatory cytokines (adiponectin - AdipQ) $[3,4]$. The activity of adipocyte hormone synthesis is influenced by the area of abdominal visceral adipose tissue. the higher the BMI, the greater the likelihood of erosive lesions of the esophageal mucosa and the development of complications [7].

In recent decades, obesity has become a pandemic. The number of overweight people among the young ablebodied population grew particularly rapidly [6]. Obesity also significantly affects the psycho-emotional state of a patient with GERD [8], reduces the quality of life and prolongs the duration of treatment of comorbidities.

Thus, the study of the mechanisms of pathogenesis, motor-secretory disorders in GERD in combination with obesity is promising and has medical, social and economic significance.
The aim of the study. To study the mechanisms of motor-secretory disorders in young patients with gastroesophageal reflux disease with concomitant obesity.

Methods and materials. 55 people with a mean age of $21 \pm 2.4$ years were examined. Of these, 27 women and 28 men. The diagnosis of GERD was made according to ICD-10, Mayo Clinic recommendations and the 2006 Montreal Consensus [9], based on a detailed survey, assessment of complaints (complaints of heartburn 1 or more times a week for the past 6 months), medical history and life, questionnaire results GERDQ (international questionnaire for the diagnosis of gastroesophageal reflux disease). Patients also underwent fibrogastroduodenoscopy, radiography, and intragastric $\mathrm{pH}$ measurement. Exclusion criteria: the presence of other comorbidities, tumors of the patient's gastrointestinal tract, Barrett's esophagus, the active phase of gastric or duodenal ulcers, endocrine forms of obesity. Obesity and its degree were determined using the body mass index (BMI), it is equal to the ratio of body weight in kilograms to height in centimeters squared. Overweight was diagnosed at a BMI of 25-29.9, and obesity at a BMI of 30 and above.

Depending on the available obesity, patients were divided into 3 groups: 1st included 18 patients with GERD (13 people - non-erosive form, 5 people erosive form) with concomitant obesity, of which 11 women and 9 men, 2nd group - 22 patients with GERD (15 people - non-erosive form of GERD, 7 people erosive form of GERD) without concomitant pathology, of which 10 women and 12 men, and the control group, which included 15 healthy people, 9 women and 6 men.

Motor-evacuation disorders were diagnosed with the help of ultrasound examination performed on the ULTIMA pro-30 device (manufactured in Ukraine): in 
the position of the patient on the left side and on the back; in the epigastric region and at the level of the projection of the esophageal orifice of the diaphragm; on an empty stomach and 5, 10 and 15 minutes after taking 0.5 liters of fluid. Determined the thickness of the esophageal wall, the diameter esophageal hiatus, the width of the lumen of the esophagus in the lower third, the presence or absence of reflux (backflow of fluid from the stomach into the esophagus) $[10,11]$. Secretory disorders were investigated by determining the gastric acid in the body and antrum of the stomach using intragastric $\mathrm{pH}-$ metry on the device IKZh-2 (manufactured in Ukraine) according to standard methods. Statistical processing of the results was performed using the statistical data processing system Statistica 6.0. Student's t-test was used in the normal distribution, and non-parametric Wilcoxon criteria were used in case of deviation from the normal distribution. Correlation analysis was performed using the Spearman correlation coefficient. Differences at $\mathrm{p}<0.05$ were considered probable.

\section{Results and discussion.}

The study found that the most common complaints of patients were heartburn (77\% of the 1st group and $84 \%$ of the 2 nd group), belching air (66\% of the 1 st group, $54 \%$ of the 2 nd group), regurgitation of gastric contents (in $72 \%$ of the 1 st group, $50 \%$ of the 2 nd group), dysphagia (in $33 \%$ of the 1 st group, $23 \%$ of the 2nd group). Indicators of the GERDQ questionnaire for the first group were $11.4 \pm 1.26$ points, for the 2 nd group- $9.5 \pm 0.9$ points (table 1.)

According to the results of the survey, it was found that the clinical manifestations in patients with GERD with concomitant obesity were more pronounced.
During the ultrasound examination it was determined that the width of the lower third of the esophagus of the subjects of the 1st group was $2.86 \pm 0.21 \mathrm{~cm}$, the 2 nd group $-2.53 \pm 0.27 \mathrm{~cm}$, the control group $-2.1 \pm 0$, $14 \mathrm{~cm}$. The esophageal hiatus in the 1st group was $2.01 \pm$ $0.11 \mathrm{~cm}$, the second group $-1.81 \pm 0.08 \mathrm{~cm}$, the control group $-1.51 \pm 0.05 \mathrm{~cm}$ (Table 2). The presence of reflux was detected in 13 persons of the 1st group, 11 persons of the 2 nd group, its volume was equal in the 1 st group to $6.3 \pm 0.3 \mu \mathrm{l}$, to the 2 nd group $-4.67 \pm 0.1 \mathrm{mkl} .(\mathrm{p}<0.05)$. It can be concluded that the values of the diameter of the esophagus, the width of the lower $1 / 3$ of the esophagus and the volume of reflux in patients with GERD with concomitant obesity exceeded those in patients with GERD without concomitant pathology.

During intragastric $\mathrm{pH}$-metry revealed: the gastric acid in the body of the stomach in the 1st group was 1.04 \pm 0.02 , in the 2 nd group $-1.23 \pm 0.03$ (at a rate of 1.80 $\pm 0,04)$. Gastric acid in the antral part of the stomach in the 1st group $-5.10 \pm 0.05$, in the second group -5.72 \pm 0.078 (at a rate of $6.75 \pm 0.05$ ) table 2. Indicators of gastric acid of the 1st group exceeded the indicators of the 2 nd group.

Thus, the indicators of motor-secretory disorders: width of the lower third of the esophagus, diameter esophageal hiatus, gastric acid are significantly higher in patients with GERD with concomitant obesity than in patients with GERD without concomitant pathology.

\section{Conclusions:}

1. As a result of the ultrasound examination, it was found that the indicators of the diameter of the esophageal hiatus, dilation of the lower third of the esophagus

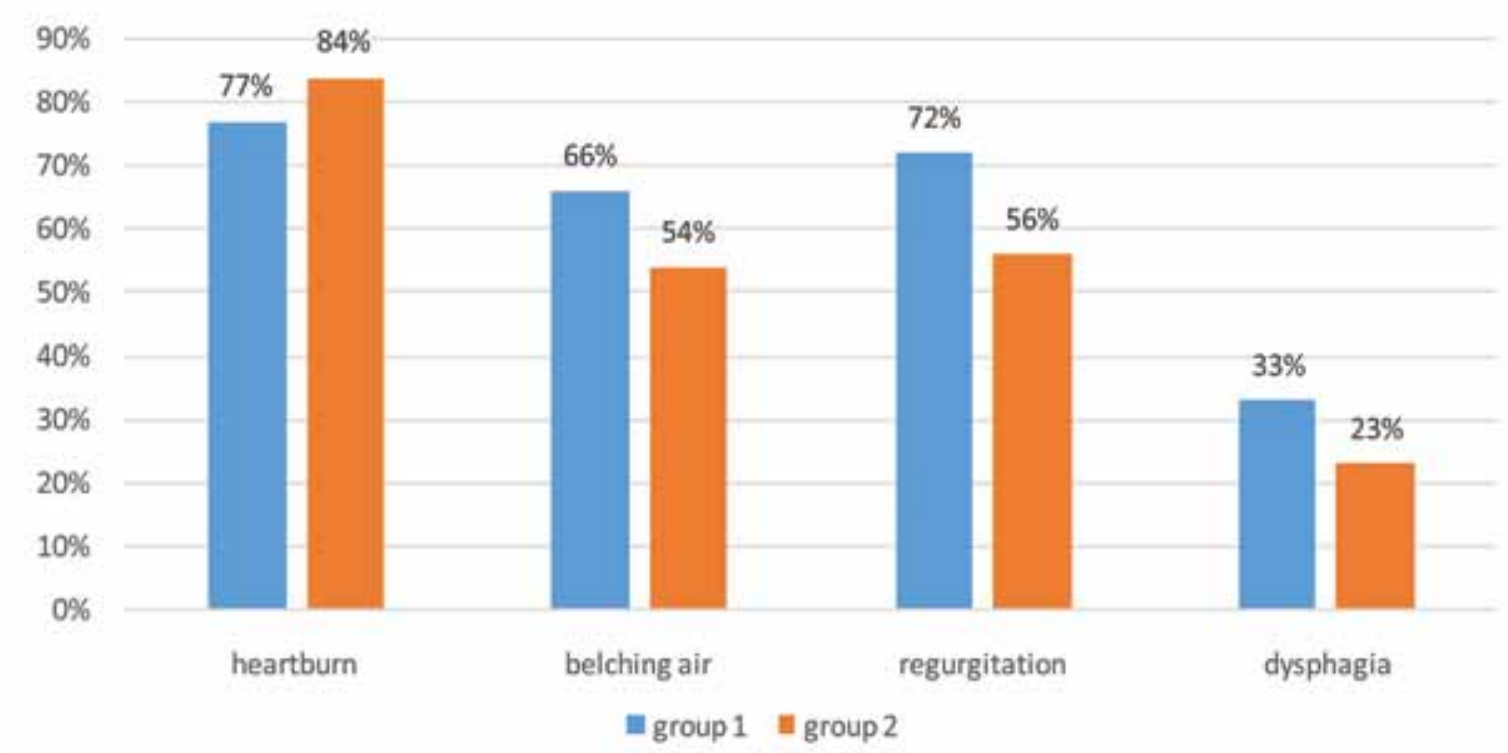

Table 1. Complaints of patients with GERD with concomitant obesity (group 1) and patients with GERD without concomitant pathology (group 2) $p<0,05$ 


\begin{tabular}{|c|c|c|c|c|}
\hline & & Group 1 & Group 2 & control group \\
\hline \multicolumn{2}{|c|}{ Esophageal hiatus (cm) } & $2,01 \pm 0,11$ & $1,81 \pm 0,08$ & $1,51 \pm 0,05$ \\
\hline \multicolumn{2}{|c|}{ Width of the lower $1 / 3$ of the esophagus $(\mathrm{cm})$} & $2,86 \pm 0,21$ & $2,53 \pm 0,27$ & $2,1 \pm 0,14$ \\
\hline \multirow[t]{2}{*}{ Gastric acid } & body of the stomach & $1,03 \pm 0,023$ & $1,11 \pm 0,026$ & $1,78 \pm 0,04$ \\
\hline & $\begin{array}{l}\text { Antral part of the } \\
\text { stomach }\end{array}$ & $5,1 \pm 0,06$ & $5,79 \pm 0,088$ & $6,72 \pm 0,05$ \\
\hline
\end{tabular}

Table 2. Indicators of motor-secretory disorders $(p<0,05)$.

and the presence of gastroesophageal reflux were significantly higher $(\mathrm{p}<0.05)$ in patients with GERD with concomitant obesity than patients with GERD without concomitant pathology.

2. It was found that, according to $\mathrm{pH}$-metry, gastric acid in patients with GERD with concomitant obesity is significantly higher than in patients with GERD without concomitant pathology.
3. The correlation between the severity of the clinical picture, the presence of excess body weight and the level of motor-secretory disorders in patients with GERD is proved.

4. The study of the peculiarities of motor-secretory disorders in GERD with concomitant pathology will improve the diagnosis, methods of pathogenetic correction and methods of prevention of complications.

\title{
List of references
}

1. Уніфікований клінічний протокол первинної, вторинної (спеціалізованої) медичної допомоги. Гастроезофагеальна рефлюксна хвороба. 2016. https://ukrgastro.com.ua/wpcontent/uploads/2017/10/Protokol-GERX.pdf

2. Wu Y.W., Tseng P.H., Lee Y.Ch., Wang S.Y., Chiu H.M., Tu C.H. et al. Association of Esophageal Inflammation, Obesity and Gastroesophageal Reflux Disease: From FDG PET/ CT Perspective // PLoS One. - 2014. - 9(3). http://dx.doi. org/10.1371/ journal.pone.0092001

3. Бабак М. О. Гастроезофагеальна рефлюксна хвороба в поєднанні з ожирінням: клініко-патогенетичні особливості, епідеміологічний аналіз та прогнозування перебігу: Автореф. дис. ... канд. мед. наук. - Луганськ, 2011. - 20 с.

4. Nocon M., Labenz J., Jaspersen D. et al. Association of body mass index with heartburn, regurgitation and esophagitis: result of the Progression of Gastroesophageal Reflux Disease stady // J. Gastroenterol. Hepatol. — 2007. — 22. - P. 17281731

5. Звенигородская Л. А., Бондаренко Е. Ю. Клинико-морфоло гические особенности гастроэзофагеальной рефлюксной болезни у пациентов с абдоминальным ожирением //Consilium medicum Ukraina. - 2012. — T. 7, № 6. - C. 3 - 7 .
6. Boeckxstaens G. Symptomatic reflux disease: the present, the past and the future / G. Boeckxstaens, H.B. El-Serag, A. Smout [et al.] // BMJ - 2014. — №63(7). - P.1185-1193.

7. Mandeep S., Joehoon L. Weight loss can lead to resolution of gastroesophageal reflux disease symptoms: A prospective intervention trial // Obesity. - 2013. - Vol. 21. - P. 284 - 290

8. Metlakunta A. S. Neuronal suppressor of cytokine signaling-3 deficiency enhances hypothalamic leptin-dependent phosphatidylinositol 3-kinase signaling / A. S. Metlakunta // Am J Physiol Regul Integr Comp Physiol. — 2011. - V.18. P.1185-1193.

9. Vakil et al. The Montreal Definition and Classification of GERD. Am J Gastroenterol 2006; 101:1900-20.

10. Oparin A. A., Lavrova N. V., Kornienko D. A. Features of Motility and Secretory Disorders in Different Forms of Gastroesophageal Reflux Disease. Bulletin of problems biology and medicine. 2013. 3: 131-133 (in Russ)

11. Oparin A, Vnukova A. The Role of Endothelial Dysfunction in the Mechanism of Gastroesophageal Reflux Disease Development in Patients with Ischemic Heart Disease. Acta clinica Croatica. 2017. 56(4):635-639. https://doi. org/10.20471/acc.2017.56.04.08

\section{Особливості клінічного перебігу та моторно-секретарних розладів при гастроезофагеальній рефлюксній роботі у пацієнтів із надлишкової ваги}

\author{
Проф. О.А. Опарін, О.М. Маляр, доц. Ю.Г. Федченко
}

Харківська медична академія післядипломної освіти

Мета:Вивчитимеханізмимоторно-секреторнихпорушеньухворихмолодоговікунагастроезофагеальну рефлюксну хворобу із супутнім ожирінням.

Матеріали та результати. У дослідженні брало участь 55 пацієнтів. До першої групи ввійшли хворі на ГЕРХ із супутнім ожирінням, друга група включала хрорих на ГЕРХ без супутньої патології, контрольна група - 20 практично здорових осіб. Проведено анкетування за допомогою опитувальника GERDQ. Peзультати показали, що скарги на регургітацію, відрижку та дисфагію були вираженішими у хворих на ГЕРБ із ожирінням. Моторно-секреторніпорушення досліджували шляхом ультразвукового дослідження та pН-метрії, при чому показники діаметра стравохідного отвору діафрагми, розширення нижньої 
третини стравоходу, об'єм рефлюктату, кислотність шлункового вмісту достовірно вищі у пацієнтів 3 ГЕРХ із супутнім ожирінням. Виявлено кореляційну залежність між індексом маси тіла, вираженістю скарг та показниками моторно-секреторних порушень.

Ключові слова: гастроезофагеальна рефлюксна хвороба, ГЕРХ, ожиріння, моторно-секреторні порушення, рН-метрія.

\section{Механизмы формирования моторно-секреторных нарушений при коморбидной течения ГЭРБ и ожирения у молодых людей}

\section{Проф. А.А. Опарин, О.Н. Маляр, доц. Ю.Г. Федченко}

Харьковская медицинская академия последипломного образования

Цель: Изучить механизмы моторно-секреторных нарушений у больных молодого возраста гастроэзофагеальной рефлюксной болезнью с сопутствующим ожирением.

Материалы и результаты. В исследовании участвовало 55 пациентов. В первую группу вошли больные ГЭРБ с сопутствующим ожирением, вторая группа включала хрорих ГЭРБ без сопутствующей патологии, контрольная группа - 20 практически здоровых лиц. Проведено анкетирование с помощью опросника GERDQ. Результаты показали, что жалобы на регургитацию, отрыжку и дисфагию были более выраженными у больных ГЭРБ с ожирением. Моторно-секреторные нарушения исследовали с помощью $\mathrm{pH}$ метрии и УЗД, причем показатели диаметра пищеводного отверстия диафрагмы, расширение нижней трети пищевода, объем рефлюктата, кислотность желудочного содержимого достоверно выше у пациентов с ГЭРБ с сопутствующим ожирением. Выявлена корреляционная зависимость между индексом массы тела, выраженностью жалоб и показателями моторно-секреторных нарушений.

Ключевые слова: гастроэзофагеальная рефлюксная болезнь, ГЭРБ, ожирение, моторно-секреторные нарушения, рН-метрия.

$$
\begin{array}{r}
\text { Контактна інформація: Опарін Олексій Анатолійович - } \\
\text { доктор медичних наук. професор, Президент Украинскої Академії Історії Медицини } \\
\text { зав. кафедрою терапії, ревматології та клінічної фармакології ХМАПО, } \\
\text { м. Харків, вул. Дарвіна, 10, р. т. (057) 711-75-00, (057) 706-46-17, e-mail: teraprevm@med.edu.ua. }
\end{array}
$$

Стаття надійшла до редакції 10.01.2021 p. 